Article

\title{
Facile and Economical Preparation of SiAlON-Based Composites Using Coal Gangue: From Fundamental to Industrial Application
}

Jinfu Li ${ }^{1}$, Changsheng Yue ${ }^{2}$, Mei Zhang ${ }^{2}$, Xidong Wang ${ }^{3}$ and Zuotai Zhang ${ }^{3, *}$

1 Department of Materials Science and Engineering, Northwestern Polytechnical University, Xi'an 710072, China; E-Mail: jinfuli@126.com

2 School of Metallurgical and Ecological Engineering, University of Science and Technology Beijing, Beijing 100083, China; E-Mails: changsheng@126.com (C.Y.); zhangmei@ustb.edu.cn (M.Z.)

3 Beijing Key Laboratory for Solid Waste Utilization and Management, College of Engineering, Peking University, Beijing 100871, China; E-Mail: xidong@coe.pku.edu.cn

* Author to whom correspondence should be addressed; E-Mail: zuotaizhang@pku.edu.cn; Tel.: +86-10-8252-4880; Fax: +86-10-6275-6623.

Academic Editor: Mehrdad Massoudi

Received: 21 May 2015 / Accepted: 13 July 2015 / Published: 22 July 2015

\begin{abstract}
The present study aims to synthesize SiAlON-based composites utilizing coal gangue. Different types of SiAlON-based composites were synthesized using coal gangue by carbothermal reduction nitridation method through control of different reaction atmospheres. The experimental results indicate that the oxygen partial pressure was an essential factor in the manufacture of SiAlON-based composites and under proper control of the atmospheres, SiAlON-based composites with different crystal structures could be synthesized. The optimum conditions of synthesis of different SiAlON-based composites were respectively determined. Based on the laboratory results, a prototype plant was proposed and constructed, and $\beta$-SiAlON composite was successfully produced using coal gangue. The synthesized $\beta$-SiAlON composite was applied in preparation of iron ladle brick instead of $\mathrm{SiC}$, which showed that the compression strength, refractoriness under load and high temperature bending strength were increased from $44.5 \pm 6.7 \mathrm{MPa}$, $1618 \pm 21{ }^{\circ} \mathrm{C}$ and $5.4 \pm 1.2 \mathrm{MPa}$ to $64.1 \pm 2.5 \mathrm{MPa}, 1700 \pm 28^{\circ} \mathrm{C}$ and $7.1 \pm 1.6 \mathrm{MPa}$, respectively. Compared with the traditional synthesis method, the present technique is expected to save energy both in raw materials and technical process.
\end{abstract}


Keywords: coal gangue; carbothermal reduction nitridation; SiAlON-based composite; prototype plant

\section{Introduction}

Rapid economic and industrial development result in enormous waste generated and disposed, leading to serious environmental hazards all over the world. Coal gangue is a problematic waste discharged from coal mining and beneficiation [1-3], which accounts for 10 to $15 \mathrm{wt} \%$ of coal production [4]. The decades of coal production have resulted in enormous amounts of coal gangue generated in every coal-producing country. The coal gangue is mostly stockpiled, causing severe environmental problems, such as acid drainage, heavy metal leaching, as well as atmospheric pollution [5-7]. The total accumulative stockpiles of coal gangue in China have reached 4.5 billion metric tons and about 659 million tons of additional coal gangue is generated per year [8].

Coal gangue generally contains high contents of silica and alumina, associated with a certain carbon content. Coal gangue with high calorific value can be used for mine mouth power generation [9]. Besides, a certain percentage of coal gangue finds application primarily in building materials manufacture, such as brick, cement, or concrete, as well as other construction fields, such as landfilling and road construction [10]. However, such applications are mostly of low economic value and have constrained transportation distance. Therefore, the alternative utilization for coal gangue as a value-added product is strongly needed.

SiAlON ceramics, including $\alpha$-SiAlON, $\beta$-SiAlON, O'-SiAlON, AlN polytypoid or mixtures of these phases, are of unique physical-chemical properties, especially in high strength, high toughness and chemical inertness at elevated temperatures. As a consequence, they can be potentially used as structural ceramics and refractories, which are of high economic value [11-15]. Traditionally, SiAlON ceramics can be synthesized using pure chemicals [14], natural minerals such as clays, which may result in high cost [16]. As coal gangue not only has high content of $\mathrm{SiO}_{2}$ and $\mathrm{Al}_{2} \mathrm{O}_{3}$ but also reserves certain carbon content, it is especially feasible to be used in SiAlON preparation by Carbothermal Reduction Nitridation ( $\mathrm{CRN}$ ) method. In previous studies, coal gangue has been successfully used to synthesize $\beta$-SiAlON and O'-SiAlON powder [17-19].

During the preparation of SiAlON materials, the partial pressure of oxygen was reported to be an essential factor and the SiAlON materials with varying crystal structures could be synthesized through properly controlling the atmospheres from the viewpoint of thermodynamic [20-23]. However, to the best knowledge of present authors, no systematic experiment of synthesis of SiAlON materials using coal gangue has been carried out so far. In the present study, a systematical investigation on the synthesis of SiAlON, including $\beta$-SiAlON, O'-SiAlON, 15R-AlN polytypoid and 12H-AlN polytypoid has been carried out using coal gangue as raw materials. The relationships between physical properties and microstructure of these SiAlON ceramics were also studied. Based on the findings of laboratory experiments, an industrial plant prototype was proposed and then established in Shanxi Province, China. The energy consumption was then analyzed based on the industrial data. 


\section{Experimental}

Coal gangue used in the present study was obtained from Shanxi province, China. The coal gangue sample was mechanically crushed and milled to a grain size of $45 \mu \mathrm{m}$. The coke and Si (74 $\mu \mathrm{m}, 98.5 \%$ purity, AR grade) were purchased from Sinopharm Chemical Reagent Co., Ltd (Beijing, China). Al ( $74 \mu \mathrm{m}, 99.5 \%$ purity, AR grade) was purchased from Beijing Chemical Co. Ltd (Beijing, China). The chemical compositions of coal gangue were determined by an X-ray fluorescence spectrometer (XRF, S4-Explorer, Bruker, Billerica, MA, USA), as shown in Table 1. It can be seen that the coal gangue contains high contents of $\mathrm{SiO}_{2}(64.84 \mathrm{wt} \%)$ and $\mathrm{Al}_{2} \mathrm{O}_{3}(27.70 \mathrm{wt} \%)$, associated with minor $\mathrm{Fe}_{2} \mathrm{O}_{3}(3.04 \mathrm{wt} \%), \mathrm{MgO}(1.11 \mathrm{wt} \%)$ and $\mathrm{CaO}(0.72 \mathrm{wt} \%)$. As the $\mathrm{SiO}_{2} / \mathrm{Al}_{2} \mathrm{O}_{3}$ mol ratio of coal gangue is approach to 4, CRN reaction of SiAlON from coal gangue can be described by the Equations (1)-(5), and the corresponding samples are designated as $\mathrm{B} \#, \mathrm{O \#}, \mathrm{R} \#, \mathrm{H \#}$, and $\mathrm{X \#}$, respectively.

$$
\begin{gathered}
4 \mathrm{SiO}_{2}+\mathrm{Al}_{2} \mathrm{O}_{3}+4 \mathrm{Al}+5 \mathrm{C}+3.67 \mathrm{~N}_{2} \rightarrow 1.67 \mathrm{Si}_{2.4} \mathrm{Al}_{3.6} \mathrm{O}_{3.6} \mathrm{~N}_{4.4}(\beta-\mathrm{SiAlON})+5 \mathrm{CO} \\
4 \mathrm{SiO}_{2}+\mathrm{Al}_{2} \mathrm{O}_{3}+4 \mathrm{Si}+4 \mathrm{C}+4 \mathrm{~N}_{2} \rightarrow 5 \mathrm{Si}_{1.6} \mathrm{Al}_{0.4} \mathrm{O}_{1.4} \mathrm{~N}_{1.6}\left(\mathrm{O}^{\prime}-\mathrm{SiAlON}\right)+4 \mathrm{CO} \\
4 \mathrm{SiO}_{2}+\mathrm{Al}_{2} \mathrm{O}_{3}+14 \mathrm{Al}+3 \mathrm{C}+8 \mathrm{~N}_{2} \rightarrow 4 \mathrm{SiAl}_{4} \mathrm{O}_{2} \mathrm{~N}_{4}(15 \mathrm{R}-\mathrm{AlN}-\text { polytypoid })+3 \mathrm{CO} \\
4 \mathrm{SiO}_{2}+\mathrm{Al}_{2} \mathrm{O}_{3}+18 \mathrm{Al}+3 \mathrm{C}+10 \mathrm{~N}_{2} \rightarrow 4 \mathrm{SiAl}_{5} \mathrm{O}_{2} \mathrm{~N}_{5}(12 \mathrm{H}-\mathrm{AlN}-\text { polytypoid })+3 \mathrm{CO} \\
4.2 \mathrm{SiO}_{2}+0.9 \mathrm{Al}_{2} \mathrm{O}_{3}+9.3 \mathrm{C}+3.1 \mathrm{~N}_{2} \rightarrow \mathrm{Si}_{4.2} \mathrm{Al}_{1.8} \mathrm{O}_{1.8} \mathrm{~N}_{6.2}(\beta-\mathrm{SiAlON})+9.3 \mathrm{CO}
\end{gathered}
$$

Table 1. Chemical compositions of coal gangue by X-ray fluorescence analysis (wt\%).

\begin{tabular}{ccccccc}
\hline Composition & $\mathrm{SiO}_{2}$ & $\mathrm{Al}_{\mathbf{2}} \mathbf{O}_{\mathbf{3}}$ & $\mathrm{Fe}_{2} \mathbf{O}_{\mathbf{3}}$ & $\mathbf{M g O}$ & $\mathbf{C a O}$ & Others \\
\hline Content & 64.84 & 27.70 & 3.04 & 1.11 & 0.72 & 2.59 \\
\hline
\end{tabular}

The materials based on Equations (1)-(5) were homogenized by agate balls milling in ethanol medium. Afterwards, they were dried and pressed (100 MPa) into $47 \mathrm{~mm} \times 6 \mathrm{~mm} \times 6 \mathrm{~mm}$ test cuboid. The samples were heated for $6 \mathrm{~h}$ at $1800 \mathrm{~K}$. In order to achieve the industrial application, the present study adopted four different atmospheres: (a) samples were placed in a graphite crucible under 99.9\% flow nitrogen which contain $0.1 \%$ oxygen ( $\mathrm{NC}$ for short); (b) samples were placed in a alumina crucible under $99.9 \%$ flow nitrogen (NA for short); (c) samples were placed in a graphite crucible under air, the volume ratio of air was characterized by $78 \%$ nitrogen, $21 \%$ oxygen and $1 \%$ argon (AC for short); (d) samples containing excess coke content of 50\% were placed in a alumina crucible under 99.9\% flow nitrogen (NX for short). Three reducing reagents were adopted in the present experiment.

The density $\left(\mathrm{D}_{b}\right)$ of the sample was measured using Archimedes immersion technique. The synthesized composites were cut into $3 \mathrm{~mm} \times 4 \mathrm{~mm} \times 40 \mathrm{~mm}$ strips, then the three point bending method was introduced to measure room temperature bending strength $\left(\sigma_{f}\right)$, and the standard equations for the strength of a bar in three point bending method are described as follows [24]:

$$
\sigma_{f}=\frac{3 F l}{2 b h^{2}}
$$

where $F$ is the load force at fracture, $l$ is the length of support span, $b$ is the specimen width and $h$ is the specimen thickness. The crystalline phases of the samples were studied by X-ray diffraction 
analysis (XRD, DMAX-RB diffractometer, Rigaku, Tokyo, Japan) with $\mathrm{Cu} \mathrm{K} \alpha$ radiation. The quantitative phase content of synthesized samples was determined by calculation of the occupation factors. The morphology of fracture sections of samples was examined by the field-emission scanning electron microscopy (FE-SEM, Carl Zeiss, Jena, Germany) equipped with energy dispersive spectroscopy (EDS, Carl Zeiss, Jena, Germany).

\section{Results and Discussion}

\subsection{Thermodynamic Analysis}

Thermodynamic assessment of the Si-Al-O-N system showed that it was beneficial to control the extra-low oxygen partial pressure during the synthesis of $\beta$-SiAlON [19,23]. When samples were placed in a graphite crucible, the oxygen partial pressure at high temperature would quickly decrease because of the reaction of oxygen with carbon.

$$
\mathrm{C}+0.5 \mathrm{O}_{2}(\mathrm{~g})=\mathrm{CO}(\mathrm{g})
$$

Assuming the Equation (7) reaches the equilibrium, i.e., $\Delta_{\mathrm{r}} \mathrm{G}_{(\mathrm{P}, \mathrm{T})}=0$, the equilibrium constants can thus be expressed as a function of temperature $(\mathrm{T})$,

$$
\lg \left(\frac{\mathrm{P}_{\mathrm{O}_{2}}}{\mathrm{P}^{\theta}}\right)=2 \lg \left(\frac{\mathrm{Pco}}{\mathrm{P}^{\theta}}\right)-8.965-(11972 / \mathrm{T})
$$

It can be seen from Equation (8) that extra-low oxygen partial pressure could be obtained through proper controlling primary parameters. The equilibrium gas partial pressure of AC and NC atmosphere at $1800 \mathrm{~K}$ are given in Table 2 [19], while the equilibrium gas partial pressure under NA atmosphere cannot be determined because there is not enough $\mathrm{C}$ to react with oxygen under flowing nitrogen. According to the thermodynamic assessment, the results show that $\mathrm{NC}$ atmosphere is the best parameter for synthesis of $\beta$-SiAlON.

Table 2. The equilibrium gas partial pressure of $\mathrm{AC}$ and $\mathrm{NC}$ at $1800 \mathrm{~K}$.

\begin{tabular}{ccccc}
\hline Parameter & $\mathbf{P}_{\mathbf{N}_{\mathbf{2}}}$ & $\mathbf{P}_{\mathbf{C O}}$ & $\mathbf{P}_{\mathbf{O}_{\mathbf{2}}}$ & $\mathbf{P}_{\mathbf{A r}}$ \\
\hline $\mathrm{AC}$ & $6.45 \times 10^{-2} \mathrm{MPa}$ & $3.47 \times 10^{-2} \mathrm{MPa}$ & $2.92 \times 10^{-18} \mathrm{MPa}$ & $8 \times 10^{-4} \mathrm{MPa}$ \\
$\mathrm{NC}$ & $9.98 \times 10^{-2} \mathrm{MPa}$ & $2 \times 10^{-4} \mathrm{MPa}$ & $9.68 \times 10^{-23} \mathrm{MPa}$ & 0 \\
\hline
\end{tabular}

\subsection{Preparation of SiAlON Composites}

\subsubsection{Synthesis of SiAlON Composites under Different Atmospheres}

The samples were synthesized under four different atmospheres at $1800 \mathrm{~K}$, i.e., the samples were prepared under AC atmosphere, NA atmosphere, NC atmosphere, and NX atmosphere, respectively. The $\mathrm{Si}, \mathrm{Al}$, or $\mathrm{C}$ powders were used as the reducing agent during the preparation of SiAlON composites. Table 3 summarizes all the synthesis parameters.

Figure 1 shows the XRD results of samples B1, B2, and B3 as the examples, respectively. It can be seen that the mullite- $\mathrm{Al}_{2} \mathrm{O}_{3}-\mathrm{SiC}, \mathrm{X}$-phase- $\mathrm{Al}_{2} \mathrm{O}_{3}-\beta-\mathrm{SiAlON}, \beta-\mathrm{SiAlON}-\mathrm{Al}_{2} \mathrm{O}_{3}$ composites are synthesized under three atmospheres. The formed crystalline phases and physical properties of the 
samples are also summarized in Table 3. It can be seen that the atmosphere has a significant influence on the formation of SiAlON composites and the physical properties of SiAlON composites. The optimum conditions for synthesis of $\beta$-SiAlON, O'-SiAlON, 15R-AlN polytypoid, and 12H-AlN polytypoid-based composites were determined as NX, NA, NA, and AC atmospheres, respectively. The density and bending strength of samples increased with increasing oxynitride phase content.

Table 3. Phase composition of samples $(\mathrm{T}=1800 \mathrm{~K})$.

\begin{tabular}{|c|c|c|c|c|c|c|c|c|c|}
\hline \multirow{2}{*}{ Sample } & \multicolumn{4}{|c|}{ Raw Materials } & \multirow{2}{*}{ Atmosphere } & \multirow{2}{*}{ Phase Composition } & \multirow{2}{*}{ Code } & \multicolumn{2}{|c|}{ Physical Properties } \\
\hline & $\mathbf{C G}$ & Al & $\mathbf{C}$ & Si & & & & $D_{b} / g_{~ c m^{-3}}$ & $\sigma_{\mathbf{f}} / \mathbf{M p a}$ \\
\hline \multirow{3}{*}{ B\# } & \multirow{3}{*}{68.8} & \multirow{3}{*}{20.0} & \multirow{3}{*}{11.2} & \multirow{3}{*}{-} & $\mathrm{AC}$ & $\begin{array}{c}\mathrm{M}(40 \%), \mathrm{C}(37 \%) \\
\mathrm{S}(23 \%)\end{array}$ & B1 & 1.63 & 7.6 \\
\hline & & & & & NA & $\begin{array}{c}X(51 \%), \beta^{\prime \prime}(34) \\
C(15 \%)\end{array}$ & $\mathrm{B} 2$ & 1.71 & 17.3 \\
\hline & & & & & $\mathrm{NC}$ & $\beta^{\prime \prime}(71 \%), C(29 \%)$ & B3 & 1.69 & 17.1 \\
\hline \multirow{3}{*}{$\mathrm{O} \#$} & \multirow{3}{*}{69.8} & \multirow{3}{*}{-} & \multirow{3}{*}{9.1} & \multirow{3}{*}{21.1} & $\mathrm{AC}$ & $\begin{array}{l}\mathrm{Si}(41 \%), \mathrm{M}(28 \%), \\
\mathrm{S}(15 \%), \mathrm{O}^{\prime \prime}(16 \%)\end{array}$ & $\mathrm{O} 1$ & 2.26 & 37.5 \\
\hline & & & & & NA & $\begin{array}{c}\mathrm{O}^{\prime \prime}(64 \%), \mathrm{S}(25 \%) \\
\mathrm{X}(11 \%)\end{array}$ & $\mathrm{O} 2$ & 2.09 & 34.6 \\
\hline & & & & & $\mathrm{NC}$ & $\begin{array}{l}\mathrm{O}^{\prime \prime}(43 \%), \mathrm{S}(18 \%), \\
\mathrm{M}(17 \%), \beta^{\prime \prime}(22 \%)\end{array}$ & $\mathrm{O} 3$ & 2.11 & 18.5 \\
\hline \multirow{3}{*}{$\mathrm{R} \#$} & \multirow{3}{*}{47.2} & \multirow{3}{*}{48.2} & \multirow{3}{*}{4.6} & \multirow{3}{*}{-} & $\mathrm{AC}$ & $\begin{array}{c}\mathrm{C}(37 \%), 15 \mathrm{R}(58 \%) \\
\mathrm{S}(5 \%)\end{array}$ & $\mathrm{R} 1$ & 1.49 & 10.8 \\
\hline & & & & & NA & $\begin{array}{c}15 \mathrm{R}(62 \%), \beta^{\prime \prime}(15 \%) \\
\mathrm{S}(17 \%), \mathrm{C}(6 \%)\end{array}$ & $\mathrm{R} 2$ & 1.98 & 38.1 \\
\hline & & & & & $\mathrm{NC}$ & $\begin{array}{c}\mathrm{C}(42 \%), \beta^{\prime \prime}(37 \%) \\
\mathrm{X}(21 \%)\end{array}$ & $\mathrm{R} 3$ & 1.96 & 28.5 \\
\hline \multirow{3}{*}{$\mathrm{H} \#$} & \multirow{3}{*}{41.5} & \multirow{3}{*}{54.5} & \multirow{3}{*}{4.0} & \multirow{3}{*}{-} & $\mathrm{AC}$ & $\begin{array}{c}12 \mathrm{H}(55 \%), 15 \mathrm{R}(24 \%), \\
\mathrm{C}(21 \%)\end{array}$ & $\mathrm{H} 1$ & 2.01 & 35.9 \\
\hline & & & & & NA & $\begin{array}{c}\mathrm{C}(53 \%), 15 \mathrm{R}(42 \%) \\
\beta^{\prime \prime}(5 \%)\end{array}$ & $\mathrm{H} 2$ & 1.86 & 24.9 \\
\hline & & & & & $\mathrm{NC}$ & $\begin{array}{c}\mathrm{C}(72 \%), \beta^{\prime \prime}(24 \%) \\
\mathrm{S}(4 \%)\end{array}$ & $\mathrm{H} 3$ & 2.00 & 22.7 \\
\hline $\mathrm{X \#}$ & 78.6 & - & 21.4 & - & NX & $\begin{array}{c}\beta^{\prime \prime}(92 \%), C(3 \%), \\
S(5 \%)\end{array}$ & $\mathrm{X} 1$ & 2.04 & 23.5 \\
\hline
\end{tabular}

Notes: $\beta^{\prime \prime}, \beta$-SiAlON; O", O'-SiAlON; X, X-phase; M, mullite; $\mathrm{S}, \mathrm{SiC}$; $\mathrm{C}, \mathrm{Al}_{2} \mathrm{O}_{3}$; $15 \mathrm{R}, 15 \mathrm{R}$-AlN polytypoid; $12 \mathrm{H}, 12 \mathrm{H}-\mathrm{AlN}$ polytypoid.

The detailed morphological features and EDS analysis results of samples B1, B2 and B3 were also measured, as shown in Figure 2. It can be seen that the shapes of the crystals are strongly dependent on the experimental conditions, i.e., atmospheres, and the crystals from B1 (Figure 2a) to B3 (Figure 2c) are mullite (orthorhombic crystal system) with rod-shape crystal, X-phase (anorthic crystal system) crystal and $\beta$-SiAlON (hexagonal crystal system) with rod-shape crystal. The detailed morphological features and EDS analysis results of samples $\mathrm{O}_{2}$ are given in Figure $2 \mathrm{~d}$. As can be seen, $\mathrm{O}^{\prime}-\mathrm{SiAlON}$ consisted of a microstructure comprising equiaxed grains with grain size in the range of $1-5 \mu \mathrm{m}$. 


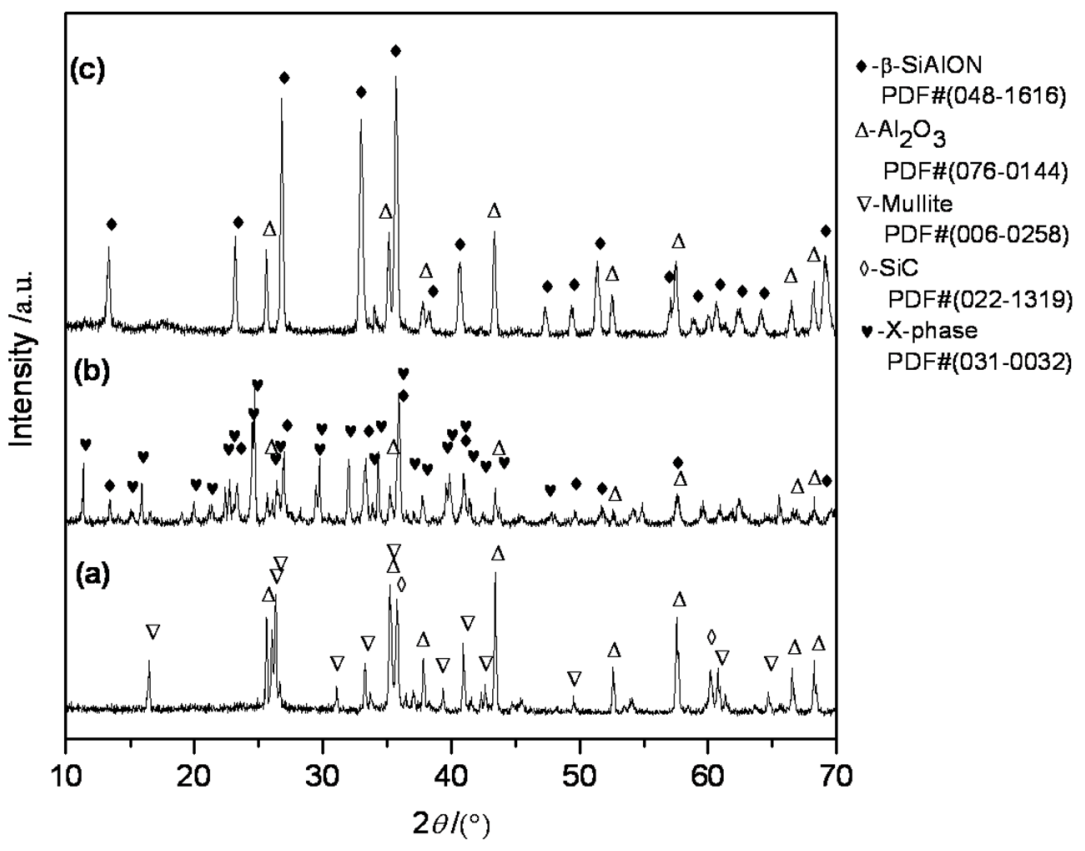

Figure 1. X-ray diffraction patterns of (a) B1 (AC); (b) B2 (NA); (c) B3 (NC).
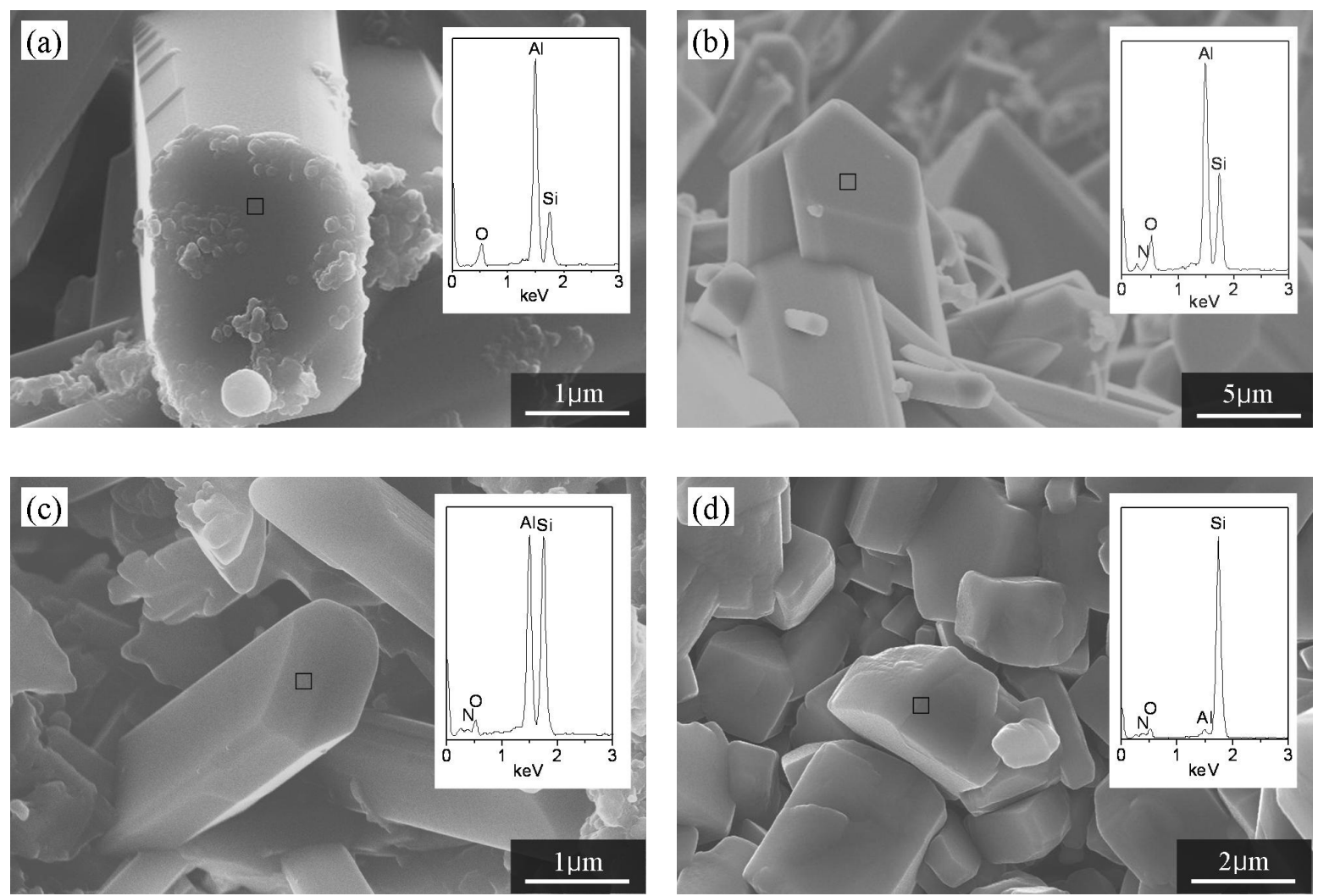

Figure 2. SEM images of fracture surfaces and EDS results of sample: (a) B1 (AC); (b) B2 (NA); (c) B3 (NC); (d) $\mathrm{O}_{2}(\mathrm{NA})$.

Figure 3 shows the detailed morphological features of different $12 \mathrm{H}$-AlN polytypoid crystal (sample H1 in AC), and the EDS analysis results of crystal. It can be seen that the12H-AlN polytypoid was found in the molded stage which had perfect crystals with regular hexagon flake structure. The thickness of the laminar grain was around $0.2-0.3 \mu \mathrm{m}$. 

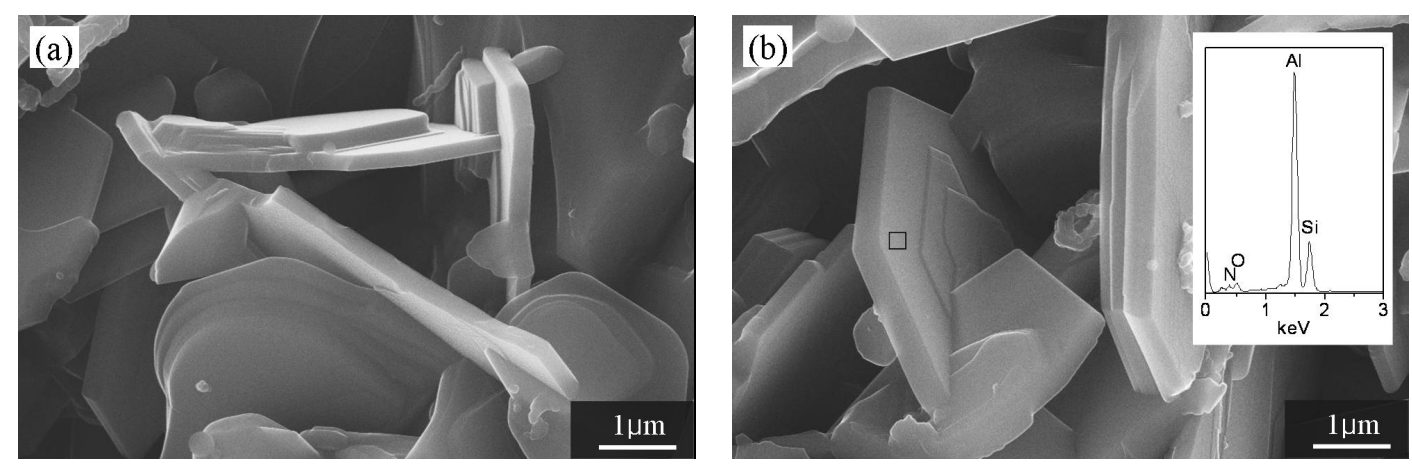

Figure 3. SEM images of fracture surfaces and EDS result of samples H1: (a) growing stage; (b) molded stage.

\subsubsection{Mechanism of Formation of SiAlON Composites}

When the coal gangue, $\mathrm{C}$ and $\mathrm{Al}$ powder compact was sintered at high temperature, $\mathrm{C}$ and $\mathrm{Al}$ combined with the oxides in coal gangue to form the intermediates. The possible intermediates are mullite, $\mathrm{SiC}$, or $\mathrm{SiO}$ gas, and the corresponding reactions can be expressed as follows [25],

$$
\begin{gathered}
4 \mathrm{SiO}_{2}+\mathrm{Al}_{2} \mathrm{O}_{3} \rightarrow 3.33 \mathrm{SiO}_{2}+0.33\left(3 \mathrm{Al}_{2} \mathrm{O}_{3} \cdot 2 \mathrm{SiO}_{2}\right)(\text { mullite }) \\
\mathrm{SiO}_{2}+\mathrm{C} \rightarrow \mathrm{SiO}(\mathrm{g})+\mathrm{CO}(\mathrm{g}) \\
2 \mathrm{Al}(\mathrm{l})+3 \mathrm{SiO}_{2} \rightarrow 3 \mathrm{SiO}(\mathrm{g})+\mathrm{Al}_{2} \mathrm{O}_{3}(\mathrm{~g}) \\
\mathrm{SiO}(\mathrm{g})+2 \mathrm{C} \rightarrow \mathrm{SiC}+\mathrm{CO}(\mathrm{g})
\end{gathered}
$$

These equations indicated the following:

(a) When the AC atmosphere was applied to synthesize SiAlON composites, mullite would be partly reduced by carbon to form $\mathrm{Al}_{2} \mathrm{O}_{3}$ [26]. Therefore, mullite, $\mathrm{SiC}$, and $\mathrm{Al}_{2} \mathrm{O}_{3}$ were detected as the main phases for sample B1 (Figure 1a).

$$
3 \mathrm{Al}_{2} \mathrm{O}_{3} \cdot 2 \mathrm{SiO}_{2}+2 \mathrm{C} \rightarrow 2 \mathrm{SiO}(\mathrm{g})+3 \mathrm{Al}_{2} \mathrm{O}_{3}+2 \mathrm{CO}(\mathrm{g})
$$

(b) When the $\mathrm{NC}$ atmosphere was adopted, $\mathrm{SiO}$ gas and liquid $\mathrm{Al}$, however, would react with the flowing nitrogen to form $\beta$-SiAlON, the reactions could be described by Equations $(14)-(16)[27,28]$,

$$
\begin{gathered}
3 \mathrm{SiO}(\mathrm{g})+2 \mathrm{~N}_{2}(\mathrm{~g})+3 \mathrm{C} \rightarrow \mathrm{Si}_{3} \mathrm{~N}_{4}+3 \mathrm{CO}(\mathrm{g}) \\
\mathrm{Al}(\mathrm{l})+0.5 \mathrm{~N}_{2}(\mathrm{~g}) \rightarrow \mathrm{AlN} \\
(2-z / 3) \mathrm{Si}_{3} \mathrm{~N}_{4}+z / 3 \mathrm{Al}_{2} \mathrm{O}_{3}+z / 3 \mathrm{AlN} \rightarrow \mathrm{Si}_{6-z} \mathrm{Al}_{z} \mathrm{O}_{z} \mathrm{~N}_{8-z}(\beta-\mathrm{SiAlON})
\end{gathered}
$$

The $z$ values of $\beta$-SiAlON synthesized under NC atmosphere can be calculated from the following equations [28]:

$$
\begin{aligned}
& a(\stackrel{\circ}{\mathrm{A}})=7.603+0.0297 z \\
& c(\stackrel{\circ}{\mathrm{A}})=2.907+0.0255 z
\end{aligned}
$$

where $a$ and $c$ are the lattice constants of SiAlON, which are determined from XRD results. The $z$ value of $\beta$-SiAlON (B3) was therefore calculated as 2.64. It was lower than the designed values as 3.6. 
The maximal $z$ value of $\beta$-SiAlON had a close relationship with synthesis temperature. High $z$ value $(z=3.6) \beta$-SiAlON cannot be obtained at $1800 \mathrm{~K}[29,30]$ and surplus $\mathrm{Al}_{2} \mathrm{O}_{3}$ phase was therefore formed as shown by XRD result (Figure 1c).

(c) When the experimental atmosphere was changed from $\mathrm{NC}$ to $\mathrm{NA}$, a large amount of $\mathrm{X}$-phase was formed. As an intermediate between oxides and $\beta$-SiAlON, X-phase was defined as "nitrogen-mullite" [11]. Compared with the partial pressure of $\mathrm{CO}$ gas under NC condition, the partial pressure of $\mathrm{CO}$ gas under NA condition was favored by way of carrier flowing nitrogen. The high content $\beta$-SiAlON therefore cannot be prepared due to the lack of sufficient reducing agent $\mathrm{C}$. The $\mathrm{X}$-phase was formed under this condition, and the pertinent reactions may be described by following equations [18],

$$
\begin{gathered}
3 \mathrm{Si}_{2} \mathrm{~N}_{2} \mathrm{O}+3\left(3 \mathrm{Al}_{2} \mathrm{O}_{3} \cdot 2 \mathrm{SiO}_{2}\right)(\text { mullite }) \rightarrow \mathrm{Si}_{12} \mathrm{Al}_{18} \mathrm{O}_{42} \mathrm{~N}_{6}(\mathrm{X} \text {-phase }) \\
2 \mathrm{Si}_{3} \mathrm{~N}_{4}+3\left(3 \mathrm{Al}_{2} \mathrm{O}_{3} \cdot 2 \mathrm{SiO}_{2}\right)(\text { mullite }) \rightarrow \mathrm{Si}_{12} \mathrm{Al}_{18} \mathrm{O}_{39} \mathrm{~N}_{8}(\mathrm{X} \text {-phase })
\end{gathered}
$$

However, as the reducing agent $\mathrm{C}$ was increased to an excess content, the relative pure $\beta$-SiAlON was therefore formed according to Equation (5).

(d) $\mathrm{O}^{\prime}$-SiAlON could be synthesized under three conditions according to the XRD results, as shown in Table 3. NA is the best condition to prepare the high content of $\mathrm{O}^{\prime}-\mathrm{SiAlON}$, and some minor phases were also found from the XRD results of samples $\mathrm{O}_{2}$ (or $\mathrm{O}_{3}$ ). Therefore, the formation mechanism of $\mathrm{O}^{\prime}-\mathrm{SiAlON}$ may be described by the following equations $[17,18]$.

$$
\begin{gathered}
3 \mathrm{Si}(\mathrm{g})+\mathrm{SiO}_{2}+2 \mathrm{~N}_{2}(\mathrm{~g}) \rightarrow 2 \mathrm{Si}_{2} \mathrm{~N}_{2} \mathrm{O} \\
0.8 \mathrm{Si}_{2} \mathrm{~N}_{2} \mathrm{O}+0.2 \mathrm{Al}_{2} \mathrm{O}_{3} \rightarrow \mathrm{Si}_{1.6} \mathrm{Al}_{0.4} \mathrm{O}_{1.4} \mathrm{~N}_{1.6}\left(\mathrm{O}^{\prime}-\mathrm{SiAlON}\right)
\end{gathered}
$$

(e) 15R-AlN polytypoid can be synthesized under AC or NA conditions, and NA was better than that of AC. AC condition, however, was the only and suitable condition for the preparation of $12 \mathrm{H}$-AlN polytypoid. The results show that the extra-low oxygen partial pressure was not always favorable for synthesis of SiAlON. At NC condition, sufficient Al as reducing agent can react with $\mathrm{SiO}$ gas under extra-low partial pressure of oxygen based on Equations (10), (11) and (14).

$$
\mathrm{Al}(\mathrm{l})+3 \mathrm{SiO}(\mathrm{g})+2 \mathrm{~N}_{2}(\mathrm{~g}) \rightarrow \mathrm{Si}_{3} \mathrm{~N}_{4}+\mathrm{Al}_{2} \mathrm{O}_{3}
$$

The formed $\mathrm{Si}_{3} \mathrm{~N}_{4}$ can combine with $\mathrm{Al}_{2} \mathrm{O}_{3}$ and $\mathrm{AlN}$ to form $\beta$-SiAlON by Equation (16), and the significant amount of Al thus disappeared. Therefore, AlN-polytypoid could not be synthesized because of the lack of AlN (by Equation (15)). It can be concluded that the proper parameter NC for synthesis of $\beta$-SiAlON is not beneficial to synthesize of AlN-polytypoid. The XRD results show that the main phases of samples $\mathrm{R} \#$ or $\mathrm{H} \#$ at $\mathrm{NC}$ condition are $\mathrm{Al}_{2} \mathrm{O}_{3}$ and $\beta-\mathrm{SiAlON}$.

\subsection{Industrial Application and Resource Consumption Analysis}

\subsubsection{Industrial Application}

Based on the previous studies, an electric resistance shaft furnace was designed with the load capacity of 15 tons and the peak temperature for the sintering temperature was $1550{ }^{\circ} \mathrm{C}$. The designed furnace has several advantages compared with the traditional furnace. First, the furnace used a continuous-type vertical nitriding furnace, instead of the traditional batch production, and the 
production efficiency is therefore improved. Second, the furnace adopted the way of top feed and bottom discharge of samples. The present designed continuous production has a good advantage that the hot nitrogen gas goes up, meanwhile the samples go down, which is favored for achieving the self-heating and self-cooling of samples, and finally achieving the high efficiency use of thermal energy. The process flow diagram of production of SiAlON composite using coal gangue is shown in Figure 4, and the industrial prototype plant of continues production of SiAlON composite using coal gangue has been conducted in Shanxi province, China, as shown in Figure 5.

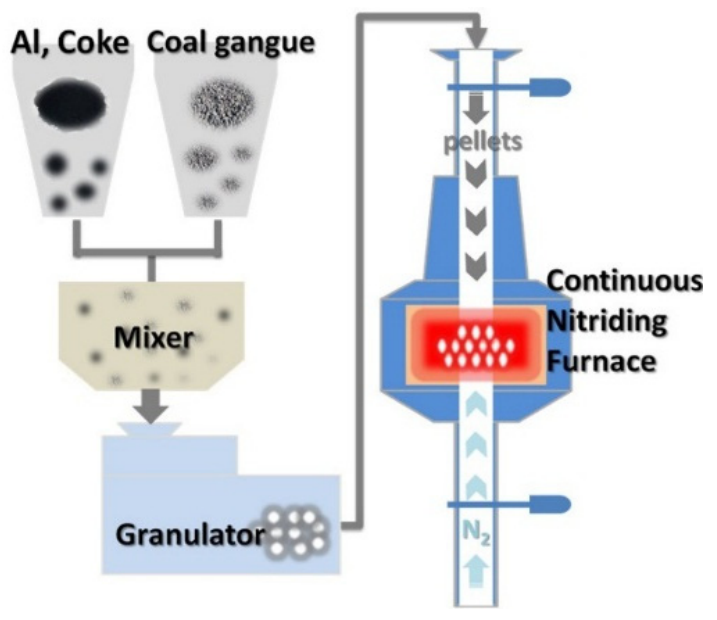

Figure 4. Process flow diagram for SiAlON production using coal gangue.

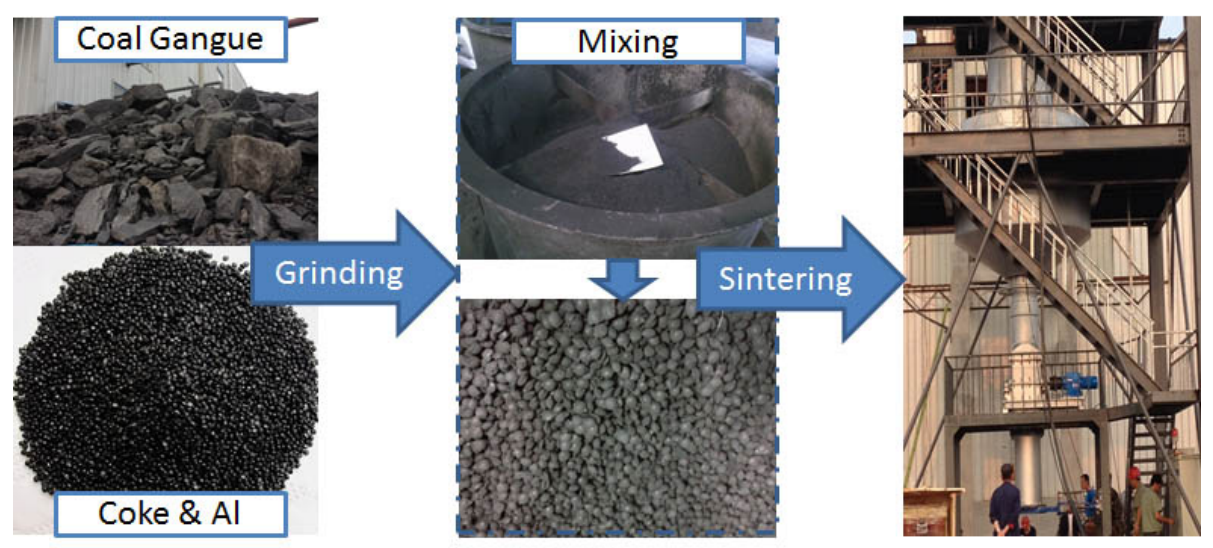

Figure 5. The continuous nitriding furnace for SiAlON production.

The plant experiment adopted the X1 experimental conditions (Table 3). The coal gangue and coke were prepared according to the stoichiometric coefficients. The raw materials then went through milling, aging, forming, heating, and sintering (Figure 5). The XRD results indicated that the obtained sample was composed of SiAlON as the main phase and X-phase as well as SiC as minor phases, which was exactly the same with the laboratory experimental result. The final products were ground to powders with 200 meshes and added into the industrial iron ladle brick instead of the SiC powders (Figure 6), and the chemical compositions of iron ladle brick is shown in Table 4. The liquid phenolic resin was used as the binding agent during the brick pressing, and baking temperature was in the range of $180-200{ }^{\circ} \mathrm{C}$ for $8 \mathrm{~h}$. The properties of prepared iron ladle brick were analyzed based on the National Standards, and the results are shown in Table 5. It can be seen that the apparent porosity slightly 
decreased from $10.1 \% \pm 1.5 \%$ to $9.9 \% \pm 1.3 \%$, while the compression strength, refractoriness under load and high temperature bending strength increased from $44.5 \pm 6.7 \mathrm{MPa}, 1618 \pm 21{ }^{\circ} \mathrm{C}$ and $5.4 \pm 1.2 \mathrm{MPa}$ to $64.1 \pm 2.5 \mathrm{MPa}, 1700 \pm 28^{\circ} \mathrm{C}$ and $7.1 \pm 1.6 \mathrm{MPa}$, respectively. The results indicated that the iron ladle brick prepared using SiAlON powders instead of SiC powders showed a better performance than the conventional iron ladle brick.

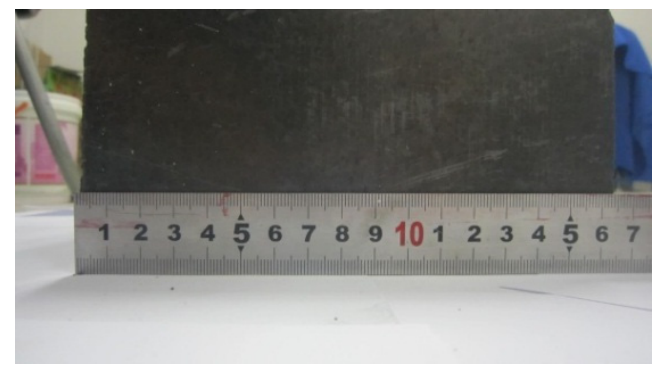

(a)

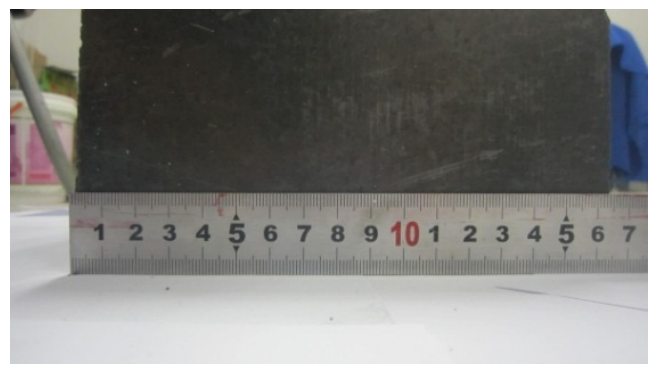

(b)

Figure 6. The photos of the iron ladle bricks with (a) SiC addition; (b) SiAlON addition.

Table 4. Chemical compositions of iron ladle brick.

\begin{tabular}{ccc}
\hline Raw Materials & Series A & Series B \\
\hline 88 Alumina $(5-3 \mathrm{~mm})$ & 25 & 25 \\
88 Alumina $(3-1 \mathrm{~mm})$ & 20 & 20 \\
Pyrophyllite $(3-1 \mathrm{~mm})$ & 15 & 15 \\
Pyrophyllite $(1-0 \mathrm{~mm})$ & 5 & 5 \\
Brown fused alumina $(1-10 \mathrm{~mm})$ & 12.5 & 12.5 \\
Brown fused alumina, $-200 \mathrm{mesh}$ & 7.5 & 7.5 \\
Graphite, -195 mesh & 5 & 5 \\
SiC, -200 mesh & 10 & - \\
SiAlON, -200 mesh & - & 10 \\
Si, -180 mesh & 1.5 & 1.5 \\
\hline
\end{tabular}

Table 5. The properties of iron ladle bricks with $\mathrm{SiC}$ addition and SiAlON addition.

\begin{tabular}{cccc}
\hline Property & Series A & Series B & Standards \\
\hline Apparent porosity, \% & $10.1 \pm 1.5$ & $9.9 \pm 1.3$ & GB/T2997-2009 [31] \\
Compression strength, MPa & $44.5 \pm 6.7$ & $64.1 \pm 2.5$ & GB/T5972-2008 [32] \\
Refractoriness under load, ${ }^{\circ} \mathrm{C}$ & $1618 \pm 21$ & $1700 \pm 28$ & YB/T370-1995 [33] \\
High temperature bending strength, MPa & $5.4 \pm 1.2$ & $7.1 \pm 1.6$ & GB/T3002-2004 [34] \\
\hline
\end{tabular}

\subsubsection{Resources and Energy Consumption Analysis}

The conventional carbothermal reduction method of SiAlON production may use natural clay as raw material [16,35], while the present study adopts the coal gangue as the raw materials instead of natural clay. Thereby, the energy consumption could originate from two factors. First, the resource consumption for preparation of each ton of SiAlON product may approximately save one ton of natural clay, i.e., around 50 US dollars was saved. Second, the carbon in coal gangue could be used as the reducing reagent, which is expected to save part of the carbon; the fixed carbon in the coal gangue is 
assumed to be $10 \%$ and then the energy saving of each ton of $\beta$-SiAlON is at least $52 \mathrm{~kg}$ of coal. Third, the adopted technique can save $20 \%$ energy compared with the traditional method, shuttle kiln. In brief, besides the environmental benefits, the adoption of coal gangue to prepare SiAlON is energy saving in both raw materials and technical process.

\section{Conclusions}

In the present study, a systematical investigation of the synthesis of SiAlON, including $\beta-\mathrm{SiAlON}$, $\mathrm{O}^{\prime}$-SiAlON, 15R-AlN polytypoid and $12 \mathrm{H}$-AlN polytypoid was carried out using coal gangue as raw materials. The results show that the synthesis of SiAlON and their physical properties are strongly dependent on atmospheres, and the optimum conditions for synthesis of $\beta$-SiAlON, O'-SiAlON, 15R-AlN polytypoid, and 12H-AlN polytypoid were NC, NA, NA, and AC, respectively. The density and bending strength of samples increased with increasing of oxynitride phase content. The synthesis of coal gangue-based SiAlON had been applied into the industrial production with an annual capacity of $20 \mathrm{kt}$ and $\beta$-SiAlON was successfully produced in an industrial prototype plant. The coal gangue-based $\beta$-SiAlON composite was applied in preparation of iron ladle brick with ambient compressive strength of $64.1 \mathrm{MPa}$ and refractoriness under load higher than $1700{ }^{\circ} \mathrm{C}$. Compared with the conventional method, the preparation of SiAlON-based composite using coal gangue has a high potential of energy saving.

\section{Acknowledgments}

Supports by the National High Technology Research and Development Program of China (863 Program, 2012AA06A114) and Key Projects in the National Science \& Technology Pillar Program (2011BAB03B02 and 2013BAC14B07) are acknowledged. The authors also acknowledge financial support by the Common Development Fund of Beijing and the National Natural Science Foundation of China (51472007, 51272005 and 51172001).

\section{Author Contributions}

The work presented here was carried out in collaboration between all authors. Jinfu Li, Mei Zhang, Xidong Wang and Zuotai Zhang conceived and designed the study. Jinfu Li and Changsheng Yue wrote the paper and Zuotai Zhang edited the manuscript. All authors read and approved the manuscript.

\section{Conflicts of Interest}

The authors declare no conflict of interest.

\section{References}

1. Zhang, Y.Y.; Ge, X.L.; Liu, L.L.; Wang, X.D.; Zhang, Z.T. Fuel nitrogen conversion and release of nitrogen oxides during coal gangue combustion. Environ. Sci. Pollut. Res. 2015, 22, 7139-7146.

2. Zhang, Y.Y.; Ge, X.L.; Nakano J.; Liu, L.L.; Wang, X.D.; Zhang, Z.T. Pyrite transformation and sulfur dioxide release during calcination of coal gangue. RSC Adv. 2014, 4, 42506-42513. 
3. Wang, X.; Zhou, C.; Liu, G.; Dong, Z. Transfer of metals from soil to crops in an area near a coal gangue pile in the Guqiao coal mine, China. Anal. Lett. 2013, 46, 1962-1977.

4. Liu, H.B.; Liu, Z.L. Recycling utilization patterns of coal mining waste in China. Resour. Conserv. Recycl. 2010, 54, 1331-1340.

5. Zhao, Y.C.; Zhang, J.Y.; Chou, C.L.; Li, Y.; Wang, Z.H.; Ge, Y.T.; Zheng, C.G. Trace element emissions from spontaneous combustion of gob piles in coal mines, Shanxi, China. Int. J. Coal Geol. 2008, 73, 52-62.

6. Nichol, D.; Tovey, N.P. Remediation and monitoring of a burning coal refuse bank affecting the Southsea Looproad at Brymbo, North Wales. Eng. Geol. 1998, 50, 309-318.

7. Ardejani, F.D.; Shokri, B.J.; Bagheri, M.; Soleimani, E. Investigation of pyrite oxidation and acid mine drainage characterization associated with Razi active coal mine and coal washing waste dumps in the Azad shahr-Ramian region, northeast Iran. Environ. Earth Sci. 2010, 61, 1547-1560.

8. The China Resources Utilization Annual Report 2012. National Development and Reform Commission, China. Available online: http://www.gov.cn/gzdt/2013-04/08/content_2372577.htm (accessed on 8 April 2013).

9. Chen, Y.R.; Zhang, L.; Ran, J.Y.; Fan, H. Experiment key factors of coal-bed gas and coal gangue co-combustion in circulating fluidized bed. J. China Coal Soc. 2009, 34, 1374-1378.

10. Zhang, Y.Y.; Xu, L.; Liu, L.L.; Wang, X.D.; Zhang, Z.T. Effects of chemistry and mineral on structural evolution and chemical reactivity of coal gangue during calcination: Towards efficient utilization. Mater. Struct. 2015, doi:10.1617/s11527-014-0353-0.

11. Jack, K.H. Sialons and related nitrogen ceramics. J. Mater. Sci. 1976, 11, 1135-1158.

12. Hampshire, S.; Park, H.; Thompson, D.; Jack, K. $\alpha$-Sialon ceramics. Nature 1978, 274, 880-882.

13. Ekström, T.; Nygren, M. SiAION ceramics. J. Am. Ceram. Soc. 1992, 75, 259-276.

14. Chen, I.W.; Rosenflanz, A. A tough SiAlON ceramic based on $\alpha-\mathrm{Si}_{3} \mathrm{~N}_{4}$ with a whisker-like microstructure. Nature 1997, 389, 701-704.

15. Wang, P.; Sun, W.; Yan, D. Mechanical properties of AlN-polytypoids-15R, 12H and 21R. Mater. Sci. Eng. A 1999, 272, 351-356.

16. Ekström, T.; Shen, Z.J.; Mackenzie, K.J.D.; Brown, I.W.M.; White, G.V. Sialon ceramics synthesized from a clay precursor by carbothermal reduciton and nitridation. J. Mater. Chem. 1998, 8, 977-983.

17. Zhang, H.J. Preparation and pattern recognition of O'-sialon by reduction-nitridation from coal gangue. Mater. Sci. Eng. A 2004, 385, 325-331.

18. Zhang, H.F.; Liu, Z.J.; Zhong, X.C. Thermodynamic study and reduction-nitridation synthesis of O'-sialon from coal gangue. J. Inorg. Mater. 2004, 19, 1129-1137. (In Chinese)

19. Yue, C.S.; Guo M.; Zhang, M.; Wang X.D.; Zhang, Z.A.; Peng, B. Controllable synthesis of high-purity $\beta$-SiAlON powder. J. Inorg. Mater. 2009, 6, 1163-1167. (In Chinese)

20. Hillert, M.; Jonsson, S. Thermodynamic calculation of the Si-Al-O-N system. Z. Fur Met. 1992, 83, 720-728.

21. Dumitrescu, L.F.S.; Sundman, B. Computer-simulation of $\beta^{\prime}$-sialon synthesis. J. Eur. Ceram. Soc. 1995, 15, 89-94.

22. Dumitrescu, L.; Sundman, B. A Thermodynamic reassessment of the Si-Al-O-N system. J. Eur. Ceram. Soc. 1995, 15, 239-247. 
23. Mao, H.H.; Selleby, M. Thermodynamic reassessment of the $\mathrm{Si}_{3} \mathrm{~N}_{4}-\mathrm{AlN}-\mathrm{Al}_{2} \mathrm{O}_{3}-\mathrm{SiO}_{2}$ system-Modeling of the SiAlON and liquid phases. Calphad 2007, 31, 269-280.

24. American Society for Testing and Materials (ASTM). Standard Test Method for Flexural Strength of Advanced Ceramics at Ambient Temperature; ASTM C1161-13; ASTM: West Conshohocken, PA, USA, 2013.

25. Xu, L.H.; Lian, F.; Zhang, H.; Bi, Y.B.; Cheng, K.; Qian, Y.B. Optimal design and preparation of beta-SiAlON multiphase materials from natural clay. Mater. Des. 2006, 27, 595-600.

26. Mazzoni, A.D.; Aglietti, E.F. Mechanism of the carbonitriding reactions of $\mathrm{SiO}_{2}-\mathrm{Al}_{2} \mathrm{O}_{3}$ minerals in the Si-Al-O-N system. Appl. Clay Sci. 1998, 12, 447-461.

27. Li, F.J.; Wakihara, T.; Tatami, J.; Komeya, K.; Meguro, T. Synthesis of $\beta$-SiAlON powder by carbothermal reduction-nitridation of zeolites with different compositions. J. Eur. Ceram. Soc. 2007, 27, 2535-2540.

28. Mazzoni, A.D.; Aglietti, E.F. Preparation of sialon alumina powders with aluminium in nitrogen atmosphere. Thermochim. Acta 1997, 298, 123-128.

29. Ekström, T.; Käll, P.O.; Nygren, M.; Olsson, P.O. Dense single-phase $\beta$-sialon ceramics by glass-encapsulated hot isostatic pressing. J. Mater. Sci. 1989, 24, 1853-1861.

30. Dong, P.L.; Wang X.D.; Zhang, M.; Li, W.C. Studies on synthesis of $\beta$-SiAlON and $\beta$-SiAlON-SiC composites. Chin. Refractories 2006, 40, 110-113.

31. Test Method for Bulk Density, Apparent Porosity and True Porosity of Dense Shaped Refractory Products, Available online: http://222.190.96.178/bzsq/firstpage/GB/Q40/GB_T\%202997-2000. pdf7081.pdf (accessed on 16 July 2015).

32. Cranes-Wire Rope-Care, Maintenance, Installation, Examination and Discard. Available online: http://vdisk.weibo.com/s/ELBPR (accessed on 16 July 2015).

33. Test Method for Refractoriness under Coad of Vefractory Products (Non-Differential with Rising Temperature). Available online: http://www.bzxz.net/e/DownSys/DownSoft/?classid=16\&id= 108964\&pathid=0 (accessed on 16 July 2015).

34. Refractory Products-Determination of Modulus of Rupture of at Elevated Temperatures. Available online: http://www.iso.org/iso/catalogue_detail.htm?csnumber=11030 (accessed on 16 July 2015).

35. Narciso, F.J.; Rodriguez, F.R. Synthesis of $\beta$-SiAlON from clays: Effect of starting materials. J. Mater. Chem. 1994, 4, 1137-1141.

(C) 2015 by the authors; licensee MDPI, Basel, Switzerland. This article is an open access article distributed under the terms and conditions of the Creative Commons Attribution license (http://creativecommons.org/licenses/by/4.0/). 